\title{
TAX EVASION AND TAX AVOIDANCE IN THE TOWNS OF THE KINGDOM OF NAPLES (XV-XVIII CENTURIES)
}

\author{
Alessandra Bulgarelli LuKacs \\ Dept. of Economics and Statistics, Federico II University of Naples, \\ NAPLES, ITALY
}

\begin{abstract}
The phenomenon of tax fraud was rooted in the tax system of the old regime. The main reasons were: the magnitude of the number of the privileged, the negotiatory nature of fiscal relations between the Sovereign and his subjects, the decentralised management of taxation where a leading role was played in this by the intermediary bodies throughout the territory. Another factor was the autonomy enjoyed at local level, which was also a source of particularism, heterogeneity and excessive power on the part of the urban élite (Fortea Pérez). Many of these characteristics, relating specifically to sixteenth and seventeenth-century Castile, were also common to other areas of Europe as a result of jurisdictional fragmentation (Epstein, Dincecco). In order to describe the peculiar physiognomy of the Kingdom in the field of tax evasion, I shall try to answer questions on whether and how this phenomenon followed the above-mentioned centuries-old patterns.
\end{abstract}

\section{RESUMEN}

El fenómeno del fraude fiscal es inherente al sistema tributario del antiguo régimen. Las principales razones fueron: la gran cantidad de privilegiados implicados en el sistema; la naturaleza per se negociadora de las relaciones fiscales entre el soberano y sus súbditos; la gestión descentralizada de los impuestos y el papel substancial que jugaron en todo ello los organismos intermedios. Otro factor fue la autonomía de que gozaron en el ámbito local, lo que era también una fuente de particularismos, así como la heterogeneidad y el poder excesivo por parte de la élite urbana (Fortea Pérez). Muchas de estas características, específicamente relacionado con la Castilla de los siglos XVI y XVII, también eran comunes a otras zonas de Europa como resultado de la fragmentación jurisdiccional (Epstein, Dincecco). Para describir la fisonomía peculiar del Reino en el campo de la evasión fiscal, voy a tratar de responder a las preguntas sobre cómo este fenómeno siguió los viejos patrones de los mencionados siglos.

KEY WORDS: privileged and not privileged, relationship between government and local communities, urban élites, catastre.

PALABRAS CLAVE: Privilegiados y no privilegiados, relaciones entre el gobierno y las comunidades locales, élites urbanas, catastro. 


\section{INTRODUCTION}

The fiscal system was the expression of the complex social architecture of the old regime where, a stratified, hierarchical society allotted legal rights and forms of taxation to each according to his social status. Reflecting the social architecture, the taxation framework provided multiple paths not only laid down by the tax authorities, but also parallel or alternative to it ${ }^{1}$.

States inherited their inability to enforce a unified fiscal and legal regime as a legacy of their medieval past. Under the old regime, the State or the Sovereign encountered difficulty in contacting the taxpayer directly and shared the tax pro quota, entrusting intermediary bodies (districts, local communities, provinces, and parishes) with the task of redistributing and collecting the taxes due to the Crown. The fiscal system would have been unable to function without such intermediaries, and the consequent dependence meant that local peculiarities had to be respected in order not to compromise the contractual logic upon which the relationship between central authority and the territory was based. Consequently, much leeway was granted at municipal level as far as the investigation and application of tax duties was concerned. Feudal lords, town councils, corporate entities and religious institutions "had considerable margins of negotiation and sometimes de facto fiscal and judicial independence"2. Jurisdictional fragmentation led to multiple coordination failures because of the high level of negotiation and the costs necessary to enforce contracts and manage tax collection.

In the Kingdom of Naples, numerous methods were applied in the field of investigation, evaluation and taxation of men and goods, employing a wide range of measures, parameters of evaluation and coin of account used in the land registries right up to the reforms of Charles III in 1740.

The measure of autonomy can be observed by the pre-eminence of local custom. In the Kingdom of Naples, the regulations issued by the capital in the Viceroy's prammatiche had only generic and theoretical validity, because in reality established custom prevailed over every other law. Furthermore, the mass of scholarly interpretation and case law were binding sources and had become embedded over the course of time. However, as they were not always in harmony, they made it difficult to identify which norms to apply. The en-

1. G. Levi (2003), 195-204; G. Alfani and M. Barbot (2009); E. Colombo (2009); M. BARBOT (2009); for the state of Milan, A. Monti (2003).

2. S. R. Epstein (2000), 14. 
tire legal system of the old regime lacked legal certainty when it came to the question of application. In such a context, it was very difficult to distinguish between evasion, which constituted tax fraud, and tax avoidance, a term encompassing all behaviour deemed lawful in itself but mainly or wholly geared towards making a tax saving.

At the local level, there was a bond of solidarity based on the ties between the individual and the community. Consequently, in the Kingdom of Naples the taxpayers had to take on the burden for those who were absent or had not paid their taxes thanks to some form of tax avoidance or evasion. This was because the universitates were called to respond to the Sovereign on the basis of the number of hearths (household) whatever the number of those who effectively carried the burden was.

To define the field of enquiry of this paper it is necessary to start from the consideration that methods of evasion depend on the type of tax and of income in question as well as the rules provided by the tax system for the application of a particular tax on a particular type of income. Specific studies have been conducted taking the main taxes as their point of reference, and their relationship to the most widespread fraud issues. In Spain, these were the alcabalas and the millones ${ }^{3}$, while in France it was the taille ${ }^{4}$. Concerning the Kingdom of Naples, I have chosen here to examine the funzioni fiscali, the main tax of the time. So all forms of illicit acts committed in the sector of indirect tax payment and thus inherent to smuggling will be disregarded, as I shall focus on the tax at the heart of the southern tax system since the reform passed by Alphonse of Aragon in 1442: the tax on hearths, was known at the time as funzioni fiscali. It consisted of a group of taxes mainly intended to cover military needs commensurate with the number of recorded taxpaying families (based on the number of 'hearths'), and was the first entry in the general balance sheet of the Kingdom: 'first' in terms of position and importance. It was imposed by the Sovereign, and was broken down pro quota among the local communities (universitates). For the calculation of burden sharing, the municipalities (universitates), distributed the burden in the form of a personal tax (tassa inter cives) to be paid by the heads of household (fuochi) according to their means as registered at the land registry ${ }^{5}$. It had a remarkable duration, lasting, with adaptations and extensions, until the arrival of the Napoleonic

3. J.I. Fortea Pérez (1987), 99-110; B. CÁRCEles de Gea (2000).

4. J. Meuvret (1971), 295-308; D.J. StuRdy (1976), 549-572.

5. M. Del Treppo (1986), 110-116; A. Bulgarelli LuKacs (1993), 116-122. 
troops in the first decade of the nineteenth century. In particular, I will examine (in section 1) the mechanisms available in the tax system for taxpayers to carry out evasion strategies, the illicit practices most commonly adopted (in section 2), and the town-country relationship as a scenario for abuse of power and tax evasion by the urban élite (section 3) and the measure to fight tax evasion undertaken by the government in order to address and eradicate such malpractice (section 4).

\section{THE UNIVERSITAS AS TAX PAYER FOR THE ROYAL REVENUES}

The local communities (universitates) were the back-bone of the fiscal system in the Kingdom of Naples (XVth-XVIIIth centuries). The ordinary and extraordinary taxes (funzioni fiscali and donativi), imposed by the government according to the number of households/hearths, formed the basis of the general balance sheet of the Kingdom, supplemented by tolls and taxes on consumption. These taxes on households were paid by the universitates after being levied from the inhabitants. As a consequence of the tax system under the old regime, the local communities were at the same time taxpayers to the royal tax authorities and tax collectors from the inhabitants. In this way they were able to practice tax evasion but they were its victims at one and the same time.

The following explanation, while not covering the entire range of solutions adopted, examines the unlawful practices that affected the economy most. They are listed in descending order of incidence according to the perception of the observers of the time.

It is opportune to start from the first phase of tax distribution in the local communities on the part of the royal tax authorities. As we mentioned above, the revenue was divided according to the number of hearths attributed to each community by means of regular census (in which the households were counted). Evasion/avoidance could thus occur by declaring fewer households than the actual number of households that the universitates comprised, in the hope of reducing the fiscal burden. However, this was no easy task because the declarations were compared with door to door findings (ostiatim) recorded by government representatives sent out to the various locations. From the disputes between the tax representatives and the local communities, which could also result in a judgment before the courts in the capital, the total number of households was established, i.e., the tax base from which the universitas 
was called to contribute to the ordinary and extraordinary taxes requested by Naples. All this procedure had a mainly fiscal aim and was the result of negotiation between the parties - between each universitates and the government officials concerning the findings on site and between the General Parliament of the Kingdom and the Sovereign when dealing with transitory adjustments between one count and another.

The final value attributed was a compromise which neither satisfied the local communities nor the government as it only partially reflected the true number of households and failed to take into account any variation over time. The calculation of revenue was determined largely by the huge number of persons exempt for various reasons, and this did not necessarily depend on the growth or diminution of the population itself.

The hub of this analysis is the relationship between the tax-paying households and those exempt and privileged. In the periods of crisis of the central decades of the seventeen hundreds, it changed so significantly as to upset the balance of the local finances. The reports sent by the universitates to the government in Naples continually insisted on the topic of those with the right to tax reductions and exemptions and fiscal avoidance carried out under the protection of exemption.

Partial or total tax exemption was recognized across a wide, varied range of categories. The requisites to gain access to such privileges extended from the age of the householder to his marital status and number of children, from residence to social status, from income to physical disability, from ecclesiastical status to military status: widows, sixty-year-olds, family nuclei with more than 12 children, minors under 14 years of age with annual income not exceeding one oncia, the disabled and beggars, missing persons and tramps, Neapolitans, foreigners, barons, priests, monks and oblates, consecrated women living at home, prisoners of the Turks and men at war, all of whom were exempt from tax ${ }^{6}$.

From the point of view of the mentality of the observers of the time or the taxpayers who were not able to enjoy such privileges, fiscal exemption did not resemble evasion at all. Here, as in France, it was not the principle of privilege to that was questioned but its extension and mode of application ${ }^{7}$. It was precisely through such aspects that evaders could commit a blatant violation of

6. L. CeRvellino (1686), 62-90.

7. J. Meuvret (1971), 301. 
compliance, managing to obtain significant tax savings at the expense of other taxpayers forced to pay higher charges.

There were at least two solutions for getting round the law and gaining protection as a regular taxpayer while evading tax: firstly, donating goods, which would have otherwise been subject to taxation, to exempt and complicit third parties. Secondly, cheating the tax system by obtaining exemption without being entitled to it.

Such manoeuvres offended the sense of justice of the population, who spoke openly in the general parliaments of the Kingdom about "abuse" and "fraud" when they reported the multiplication of the number of lay clergy who used this system to enjoy the two privileges of the court and the tax system $^{8}$. The area where the most unlawful tax get-outs were used was that of the Church, with exemption and privileges extending beyond measure through the collusive action of bishops and other prelates.

Of all the exemptions, the matter of the secular clergy remained unresolved for a very long time and was the focus of denunciation of the evasion primed by such immunity, extended duplicitously also to the goods of lay people. The problem was clearly evident because evasion had reached an unbearable scale in the decades between the sixteenth and the seventeenth century. Receiving minor orders did not require the holder to wear ecclesiastical garb or to abide by vows but essentially attributed the two privileges of the court and the fiscal system which, after they had been obtained, were defended by the bishops at pain of excommunication in the eventuality of these rights being questioned by the municipal authorities. It is clear that those who could do so tried to gain immunity, so ordinations multiplied in the years of the negative economic trend in response to a growing demand. By now, not only humble people who normally worked in the lower, day to day running of the Church ('rough-mannered' lay clergy), but also "los mas facultosos y poderosos" an expression above all referring to the local, most powerful élite - received Orders 9 .

8. About the 1611 Parliament, Biblioteca Nazionale di Napoli (from now on BNN), ms., Biblioteca Brancacciana, V B 6, f. 94; about the 1613 Parliament, ibid., f. 116.

9. Archivio di Stato Vaticano (from now on ASVa), Segreterie di Stato, Napoli, vol. 26, nunzio Cesare Monti, p. 108. 


\section{THE UNIVERSITAS AS TAX COLLECTOR}

The perception of tax evasion, as a phenomenon which damaged not only the community but also the individual taxpayer, was widespread throughout the Kingdom. The principle "if everybody paid, everyone would pay less" was very clear in its essential simplicity also to the peasants in the southern countryside. It was even more coercive due to the principle of joint liability in force in the universitates.

The notes by Scipione Monaci, a tax collector in Calabria Citra, are of interest, as they pay particular attention to the subject and underline the existing close interrelations between the strongest groups among civil society and the highest ranks of the ecclesiastical hierarchy in the provinces:

a part of the inhabitants, the Rich and Powerful, have taken on the clergy's vestments, cheating the Royal Court, and as such they have been defended by their bishops with great determination, who, not content with this, encourage the married clergy to enjoy fiscal immunity on a daily basis disobeying the rules (as known to your Lordship) of the Sacred Canons and sacred Council of Trent ${ }^{10}$.

From the document, the variety of figures on the fringe of the ecclesiastical world also emerges. They too were gradually included in the category of the exempt: clergy of minor orders, married clergy, lay deacons, oblates, guardians of ecclesiastical territory, servants in the bishop's house, etc. Disregarding all existing regulations, they were made exempt from taxes under the protection of archbishops and bishops who "with warnings and excommunication" blocked any possible action by the local administrators ${ }^{11}$. In January 1628, the city of Cosenza, the capital of the Calabria Citra province, recorded 208 clergymen of whom only 3 had the full dignity of clergymen and 25 priests. Despite this, all of them took equal advantage of undue tax exemptions and the wealthiest families in the city were allowed to be exempt from taxes. In confirming the treasurer's observations it was also noted that the communities of canons regular were expanding into the urban areas to occupy the physical space left free by the outgoing population ${ }^{12}$.

10. Archivio di Stato di Napoli (from now on $A S N$ ), Camera della Sommaria, Attuari Diversi, fs. 167, Atti riguardanti l'appuramento e dimostrazione delle Università impotenti del Regno, f. 16.

11. Ibid. ff. 221,229 e 234 .

12. N. Faraglia (1883), 391. 
Similar remarks can be found in the other provinces of the Kingdom, too. It may be said that no universitas missed the opportunity to underline this phenomenon in every report to the Neapolitan government. In order to achieve better information the government drew up lists of the citizens to be defined as ecclesiastics ${ }^{13}$. The proposed remedies to slow down the widespread phenomenon of exemption through ecclesiastic title consisted solely in reinstating existent but scarcely respected pontifical regulations which could be reinforced by direct Papal intervention vis-à-vis the bishops and clergy in the provinces. "With very strict orders" he would limit the exemptions to the mere "manly dowry obliging them to pay tax on goods obtained through sale or donation ${ }^{14}$.

The ecclesiastic sector was surely the most substantial source of tax exemption and subtracted a huge mass of goods, by right and by deed, from the tax authorities. However, this was not the only one, as already seen from the list of those exempt from taxes. Loopholes could be sought in every category. For example, enlistment, becoming a soldier, could constitute a possibility of escape from taxes guaranteeing exemption from payment. A variety of ranks and functions from battalion soldiers, light horsemen, and men of arms to the castle guard contributed at local level to the reduction of the tax base of the municipal revenue. The feudal sector was an obvious scenario for the circumvention of regulations where, under the exemption granted to his status, the baron was able to include all the servants of his court among which were sometimes listed even the tenants of the feudal lord's property ${ }^{15}$.

Finally, it is worth recalling the evasion committed by the non-privileged. Ordinary people had a different way of evading taxation. For those who found no useful expedient to avoid taxation, the only way to escape taxation was by moving away from their residence. I found a growing tendency towards mobility on the part of the population made unstable due to the economic crisis in the first decades of the seventeenth century ${ }^{16}$. During crisis periods, the taxable population shrinks in the settlements as a result of the growing number of those who escaped tax payment. In this way the remaining taxpayers numbered the most defenceless exponents of the population, namely those

13. P. Sposato (1965) e $A S N$, Camera della Sommaria, Diversi I, fs. 19, I and II.

14. Atti riguardanti l'appuramento, cit., f. 17; in those years, the city of Aquila had deliberated the sending of its own delegation to Rome to obtain the elimination of ecclesiastical immunity directly, Archivio di Stato dell'Aquila (from now on ASA ), Archivio Civico Aquilano, Libri delle Reformagioni, b. T31, 7 agosto 1623, f. 133.

15. Atti riguardanti l'appuramento, cit., f. 234.

16. A. Bulgarelli LuKacs (2009). 
who worked for a living. As Squillace's universitas (Calabria Ultra) observed, taxation was imposed only on "skilled workers, farm-hands and others from the lower levels of the population" 17 . However, the dues to the royal court remained the same due to the slow up-dating of the census.. At municipal level it was necessary to compensate for the fall in income caused by evasion with the growth of the pro capita fiscal burden weighing heavily on those already paying tax. The internal distribution of the burden within the towns thus required higher rates per household, which the remaining families found it difficult to comply with. Not being able to bear the burden, many taxpayers ended up moving away from their place of residence, which consequently recorded, and suffered from, a drop in the number of households ${ }^{18}$. Such declarations and the provincial treasurers' and collectors' annotations which reported a dramatic shortage even reaching half the number of inhabitants, are to be read from a strictly fiscal perspective ${ }^{19}$.

Sometimes it was a question of a temporary move with the sole aim of avoiding tax "...no further than one, two, four or six miles and up to twelve or fifteen miles," keeping their jobs; such commuters "...every day checked their possessions and farms and returned to the places they came from...," as the treasurer of Calabria Ultra Giuseppe Prieto reported to the government in 1624 when he asking for those people to be obliged to pay taxes in full. $\mathrm{He}$ proposed a possible system of varying degrees of tax burdens according to distance when this was over 20 miles. His aim was to safeguard the remaining taxpayers called by the government to contribute all the same as they had a number of households which no longer corresponded to reality and they would otherwise be forced to abandon the depopulated territories ${ }^{20}$. In addition, some moved away permanently as it was customary to move into and out of the Kingdom in response to demand for seasonal workers in agriculture and transhumance. The attraction of the Papal State on the one hand and of Sicily on the other on the provincial areas of the borders of the Kingdom is widely attested. The solutions for passing from a "conservation-oriented" model of migration, which tended to maintain relationships with the place of origin, to one of "rupture", involving a definitive transfer from the habitual home, were to be found in the numerous routes existing at the time and the variable intensity of flow. Obviously, the choice did not depend only on fiscal reasons

17. Atti riguardanti l'appuramento, cit., f. 235.

18. Atti riguardanti l'appuramento, cit., f. $235 \mathrm{v}$.

19. See Caridà and Mileto (Calabria Ultra), ivi, ff. 209-11 e 237-40; ff p. 21v and 24.

20. Atti riguardanti l'appuramento, cit., ff. 218-224. 
and it is not possible to define how much they counted. There were reasons of repulsion and of attraction surrounding the tax problem and the different burdens incumbent on one settlement rather than another played a part in determining choices.

\section{FISCAL EVASION IN PROVINCIAL TOWNS: THE CHOICES OF THE POWER ELITES}

Now we arrive at the more specifically urban aspect. Before looking at the phenomenon of tax evasion, we need to recall a few fundamental characteristics of the provincial towns in the Kingdom of Naples. They were conditioned by the precocious dominating presence of the monarchy and the power of the feudal system. Their roles and functions were compressed. Moreover, during the centuries of Spanish dominion, they had also been penalised by royal financial politics which had been spread over many areas in the relentless search for income, and had led towns into a progressive loss of State property or royal status, increasing expenses and an imbalance in the municipal budgets, with a gradual reduction in municipal property and the sale of subordinated communities or the separation of those that had become autonomous $^{21}$. The government's choices were balanced by the greater autonomy of the municipal élite. The local power groups had a free hand in the tax sector apart from the obligation to communicate their choices to the government bodies in the capital, and these did not withhold their consent. In the name of local custom a wide range of solutions regarding taxation methods, measures, assessment parameters and coin of account could be put applied, as the land registry was the only instrument for checking the taxable amount due.

In terms of the role played by the mas poderosos as the main perpetrators of tax fraud, the experience of the Kingdom was similar to that of Spain. Arbitristas like Sancho de Moncada and Caxa de Leruela highlighted this phenomenon referring to the management of the millones tax entrusted to their care $^{22}$. In the towns of the Kingdom, evasion was planned before the tax burden within the municipalities was distributed. The lack of a land registry or any updating was the main way to conceal wealth from tax assessment, preferring highly regressive means of taxation (tolls and excises). The unequal

21. A. Musi (2000), B. Salvemini (2000 and 2006).

22. B. CárCeles de Gea (1994). 
distribution of the fiscal burden was evident both within the town walls and outside in the interrelationship with the surrounding countryside.

This paper focuses solely on the evasive practices committed by the cities and their inhabitants with respect to the surrounding municipal territory.

It is known that the conflictual relationship between the town and the countryside or between universitas and minor settlements with no autonomy (villages, hamlets, castles) found a fertile battleground in the tax sector because of the distribution of tax burdens to the advantage of the dominant town. In particular, the tax (bonatenenza) due from owners, including the feudal lord, of goods and property of an allodial nature owned in the countryside, was a highly controversial topic ${ }^{23}$. The fiscal burden was supposed to fall principally on individuals as far as property owned outside the urban walls was concerned, as they were non-residents. This tax was subject to strong contestation. In the territories surrounding hamlets and villas, most properties belonged to the inhabitants of the town. They avoided tax obligations because they did not register them in the land registry. This evasion led to law suits that would last over time and which continued for centuries without reaching an adequate solution. The case of the castle of Pizzoli in the countryside of L'Aquila is an example. It was annotated as follows in 1717:

most of these territories, whether arable or vineyard, planted with canes or meadows, belong to citizens of L'Aquila, who, to avoid bonatenenza, do not register the property they possess, nor can information regarding them currently be obtained from farmers because almost all of them are in the country around Rome ... and the women do not know who owns the land which they claim is rented... ${ }^{24}$.

This was a thorny question given the fact that the property in question could reach sizeable dimensions and thus form a precious taxable source of considerable weight as part of municipal revenue going a long way to enabling compliance with obligations towards the government.

On the other hand, the main evaders of this tax were barons and local clergy and the municipal administration responsible for taxation was unable to withstand their enormous power. In fact, Terlizzi (Terra di Bari), evader of

23. In the hamlet of Santa Sofia (Calabria Citra) more than $70 \%$ of the agrarian income was in the hands of the bonatenenti, V. GiURA (1987), 197-215; on the bonatenenza, L. CERVELLino (1686), 90-120; N.A. Marotta (1642). See the case of Bari, S. Russo (1991), 82-91.

24. ASN, Camera della Sommaria, Catasti antichi, vol. 9, pp. 238-39; ASA, Archivio Civico Aquilano, fss. U. 3, II, U 5, f. 173, U 35, I, X 45, X 37, X 24, X47 and X 48. 
bonatenenza for about fifty years due to local church pressure, no longer compiled its land registry ${ }^{25}$. The Church, being entitled also to goods belonging to other third parties, who thus managed to evade the tax, did not hesitate to threaten urban administrators who expected to proceed with tax collection with excommunication. "Imposing tax and squeezing the bonatenenti" were, for the President of the Udienza Provinciale (the second level court) of Calabria Citra, the expedients to adopt in order to gain the arrears and current dues from the università of Montalto which defaulted in payment to the sovereign ${ }^{26}$.

The government was fully aware of the importance of such taxes for local finances and, from the years following the tax revolt of 1647-48 and then in 1682, 1704 and 1729, it issued prammatiche and regulations on the specific subject of bonatenenza within the context of provisions designed to restore fiscal order and remove the causes of difficulty in local finances. It was found that evasion of such tax, committed firstly by feudal lords, constituted the primary form of default by communities towards the royal tax authorities and their creditors and the obligation upon barons to pay tax was confirmed, ordering the Camera della Sommaria (the upper financial court in Naples) to issue the necessary regulations to enforce it and delegating the collection of the amount unpaid by the barons to the Udienza Provinciale and their military sector ${ }^{27}$. Also the primary aim of the special institution Giunta per il Buon Governo delle Università in 1729 was to re-establish regular collection of the bonatenenza, forcing evaders to pay not only the current but also the previous ten years' taxes $^{28}$.

The cadastre was the main tool for calculating the relative tax base. The inadequacy of existing censuses, which were rarely updated, or their total absence made it impossible in practice to identify the goods held by foreigners and to define the nature of their possession ${ }^{29}$. There was total confusion when it was necessary to distinguish the "feudal bodies" from the non-feudal ones among the local baron's property as the president of the Sommaria, Garofano, observed, "There is great confusion in the documents and it is impossible to

25. ASN, Camera della Sommaria, Conti delle Università, fs. 575/2, 26 maggio 1729 and fs. 875.

26. ASN, Camera della Sommaria, Notamentorum, vol. 181, 24 maggio 1740.

27. L. GiUSTINIANI (1803-1808), t. XV, tit. CCLXXXI, pramm. XXVI, 19 agosto 1652, 134 35; t. I, tit. VI, pramm. XX, 13 maggio 1682, 289-90; ASN, Camera della Sommaria, Notamentorum, vol. 145, 14 febbraio 1704, f. 192.

28. A. Bulgarelli LuKaCs (2004), 42, 69-84.

29. Ibidem, 111-127. 
take the proper decision" ${ }^{30}$. Only the compilation of the land register could allow the attribution of the quantity and quality of property to be taxed for the bonatenenza with certainty ${ }^{31}$. The absence of such a tool formed a pretext for sine die postponement of the payment due ${ }^{32}$.

It was a particularly widespread situation in the urban environment where commercial and economic activity could allow a tax system based almost completely on tolls and duties which was the reason why the cadastre could only be drawn up for the collection of bonatenenza. Regarding this point the city of L'Aquila wrote:

... But since we do not live according to the land register in this city but rather by various impositions on almost all provisions and on various jus prohibendi which being known to be insufficient to satisfy the Royal Court, were applied in the old times, prior to royal approval, and other new taxes were added... with the lack of the said land register there is no other way for us to quantify the citizens' property and still less that of outsiders other than what they themselves declare... ${ }^{33}$.

Other initiatives were added to these forms of fraud clearly evident to the observers of the time, and the taxpayers were called to pay with higher dues. Unlike the former, they were able to pass unobserved hiding behind the tax procedures at local level. Tax base was established through an algebraic calculation. Both costs relating to the management of work, with eventual losses accumulated over the year, and those related to the maintenance of the family itself were subtracted from the sum of all the elements which defined the whole position of the components of the nuclear family (income from work, value of goods and property owned). This variable, used in defining the tax base, was able to bring about substantial modifications in the calculation and final values ${ }^{34}$. In this case it was not a question of being able to conceal wealth, but rather to make a higher declaration of expenses in order to obtain tax reductions. Recourse to such evasive practices was made possible by the

30. ASN, Camera della Sommaria, Notamentorum, vol. 180, a. 1739, 16 giugno.

31. The Camera della Sommaria observed in this way regarding the case of Palmarici, ASN, Camera della Sommaria, Notamentorum, vol. 181, 17 marzo 1740.

32. The taxation rate was no longer lower than that of the inhabitants because the bonatenenti, compared to the latter, had to contribute only regarding the university commitment with the government (a tax of 42 carlini per hearth). See the dispute between Scafati community and its bonatenenti, ASN, Camera della Sommaria, Notamentorum, vol. 157, 21 febbraio 1715.

33. ASA, Archivio Comunale Antico, U 94.

34. A. Bulgarelli LuKacs (1993), 135-145. 
mechanism for assessing the tax base which used a criterion of assessment for each household net of expenses.

The criterion could not avail itself of defined, univocal parameters for implementation, however widely referred to in scholarship and doctrine. Also the 14th century commentary on the cadastral rules, De forma appretii faciendi iuxta cap. reg. declarata, constantly consulted and reprinted over the centuries as an essential reference, offers concise references on the subject ${ }^{35}$. The author, Pietro Piccolo of Monteforte, a renowned jurist and intellectual in fourteenth-century Naples, focuses only on the distinction between necessary and voluntary expenses and, in so doing, excludes the latter from any possible tax deduction. The deductible amount of the former had to be calculated on the basis of the taxpayer's state and situation, i.e. his ability to consume, all the while allowing for a wide margin of variation. The subjective nature of the tax was raised yet again and there were wide openings for municipal discretion regarding the shaping of the size of the tax base for each household. In this way, the differences in the wealth possessed by the taxpayers could be cancelled out by means of suitable manoeuvres regarding the deductible expenses which were increased thanks to the complicity of the municipal administrators appointed to make the calculation ${ }^{36}$. The vagueness of the rules and the way in which they were applied made possible all sorts of abuses reinforcing the clear inequality of the distribution of the tax burden under the Old Regime.

\section{THE FIGHT AGAINST TAX EVASION}

Losing family units did not only mean losing taxpayers and worsening the burden of those remaining. We must add to the microeconomic consequences of tax evasion involving the single taxpayers, macro effects appreciable both at municipal and royal levels. But before looking at the financial aspects it is necessary to underline the role played by men in pre-industrial economies. Men and natural resources constituted the main factors in producing the primary wealth of the settlements. Variations in their volume formed a reference of great importance which the real economy had to take into account in a period when the relationship between population and resources influenced the dynamics.

35. First issue, Naples 1572.

36. P. Piccolo Di Monteforte (1572), 3. 
On the financial level, a reduction of taxable households compared with the government count meant a reduction in the taxable income of the local communities and the municipal budgets recorded imbalance and deficits. At aggregate level, the financial difficulties of the local communities affected the capital of the Kingdom due to the lack of compliance with obligations to the royal tax authorities. Evasion obviously damaged the general balance sheet of the Kingdom due to the missing income from the main revenue (funzioni fiscali) with consequences on public debt. The lack of income flow did not push towards a reduction of expenses. On the contrary, Spain's war demands on the European chessboard tended to grow. Rather, the practical solutions were increased rates and/or recourse to debt in order to obtain the resources lacking on the financial side.

Estimating the extent and the long term trend of tax evasion under the old regime by measuring the total taxes due but unpaid taxes every year is a difficult task considering that still today it is difficult to obtain complete and coherent data to allow a comparative analysis. While it is impossible to calculate the tax gap for the past, it is at least possible to reconstruct the tools available to Sovereigns for tax inspection on the territory and the possible actions to combat evasion.

The Kingdom of Naples had some particular characteristics in which it differed from the initiatives for reinforcing the Crown fiscal apparatus in the periphery as in other European states. In Spain, to which the Kingdom found itself subjected for more than two centuries, the figure of the corregidor, the royally appointed official sent to the cities and the country to preside over municipal meetings, had his duties extended over time to act as judge of first instance and chief of police ${ }^{37}$. At the end of the mandate, he was subjected to an external evaluation or juicio de residencia (Castille), or purga del taula (Catalonia), enquesta (Aragone), inquisiciò (Valencia), like all officials appointed for jurisdiction. This procedure, originally set up only for specific cases, became normal and periodic practice, providing a complete investigation into every aspect of municipal government, in which the redición de cuentas (auditing) played a central role ${ }^{38}$. As we mentioned above, this institution was

37. On the figure of the corregidor, B. GonzÁlez Alonso (1970) (1978), 193-248; A. BerMúdeZ (1974); A.C. MERCháN FernándeZ (1988), 78-87; C. GARRIGA (1991), 215-389; M.J. Collantes de Terán de la Hera (1998), 151- 184; J.I. Fortea Pérez (2012), 97144.

38. J. Lalinde Abadía (1965), 499-523; T. Canet Aparisi (1987),131-150; M.J. Collantes de Terán de la Hera (1998), 163-164, 172-173. 
used in combination with the Monarchy's attempts to reorganise municipal government ${ }^{39}$. There were also control initiatives of an extraordinary nature (pesquisas and visitas), whose variety of procedures and areas of enquiry had the main purposes of monitoring and inspecting the public accounts (fiscalizacion). From the end of the fifteenth century there was no distinct separation between pesquisa and visita, as shown by the adoption of compound terms (pesquisa de residencia or visita y residencia among others) ${ }^{40}$. In their varied guises, these means of inspection were in any case able not only to provide information on the local communities and the peripheral institutes of the Kingdom of Spain, but also on the other provinces of the Empire ${ }^{41}$ : reports, censuses, financial accounts and also minutes and documentary material produced by the bodies which controlled the peripheral administrations and by those appointed periodically by the Crown in order to carry out inspections. One of the better known examples, in that it became a constant point of reference in the centuries to follow and in the collective memory, was the pesquisa, which gave birth to the Becerro de las Behetrias de Castilla. It consisted in a reconnaissance of two thousand settlements situated within a large district located north of Duero in order to supply specific information on the king's rights and those of the feudal lords ${ }^{42}$.

In the Kingdom of Naples, from the Middle Ages, government practice had been diversified and endowed with mechanisms whose aim was to assert the sovereign's authority over his territory and hence his power of control and ability to enforce the rules ${ }^{43}$. Enquiries (inquisitions) had been foreseen even from the time of Federico II's constitutions (Melfi, 1231). Their different procedures (general, special, ordinary and ex officio) highlighted a custom which was consolidated over the course of the century through the transformations which the early Anjou sovereigns had been able to bring about. Their objectives essentially dealt with controlling the actions of the royal officials in particular and sensitive areas of justice, i.e., the taxation system and the royal estate. The aim of the actions was to obtain information, and it represented the main means of knowledge as regards the periphery of the Kingdom ${ }^{44}$. The path outlined during the thirteenth century underwent interruptions and

39. B. González Alonso (1978), 233-35; J.I. Fortea Pérez (2003), 180.

40. B. GonZÁlez Alonso (2000) 264-65.

41. J.M. BERNARDO ARES (1998), 69 ss.

42. C. Estepa Díez (2003).

43. P.F. Fournier and P. GOUÉBin (1959); J-P. BOYER (1994), 1-26.

44 S. Morelli (2012), 62, and 254-273. 
distortions and right from the beginning of the fourteenth century a series of changes occurred which contributed to the weakening of the figure of the representatives of power and the Sovereign's authority (Anjou judges/giustizieri and Aragonese viceroys /viceré in the provincial districts, and captains in the individual settlements) ${ }^{45}$.

At the same time the autonomy of the local communities was legitimated by virtue of the ancient foundation, dating back even before the Roman age, of the longstanding local customs and traditions, recognised as having equal or higher value than the sovereign's laws, and especially by virtue of the important functions they were involved in for the organization of the territory (defence, military recruitment, civil and criminal jurisdiction) as they were the main taxpayers in the Kingdom. The local oligarchies, consolidated in their own position within the municipalities, took control of the governmental and representative organs (local parliaments) while the figure of the sovereign's agent was losing authority. The capitano o governatore (captain or governor), who could be equated with the Spanish corregidor, was gradually deprived of his prerogatives and was less visible in the territory, and was mostly to be found only in the few royal cities which still existed in the Kingdom ${ }^{46}$. As a result of this process of increasing autonomy, control of the municipal administrators performance no longer followed the normal procedures of the central apparatus but was entrusted to figures (sindacatori and razionali) nominated by the municipalities themselves even for important sectors such as the accounting audit of the balance sheets ${ }^{47}$.

In those centuries of the early Modern Age, dialogue between the Sovereign and the communities focused on mediation. As we said above, the royal tax authorities did not reach the taxpayer directly but entrusted the task to the local communities that shouldered all the risks, including tax evasion in its multiple forms. In effect, the whole management of the local balance sheet remained for a long time in the hands of the élite, leaving to the capital only supervision and information concerning the choices made. All the phases of the tax proceedings, from ascertaining the taxable base to the risks in tax collection, as well as actions against tax evasion, remained the municipality's responsibility. The Sovereign only required the local administrators to fulfil tax obligations completely and punctually. Commitments to the royal tax au-

45. M. Del Trepro (1986), 165-166.

46. G. Vitale (2010), 53-72. On Pragmatic see L. Giustiniani (1803-08), III, tit., XX, 269270.

47. M. Peytavin (2003), 125-26. 
thorities were the first to be met by the local communities each of which had to respond. This constituted a sufficient guarantee for the Crown, along with the coercive power at its disposal.

Even with defaults and delays, the system seemed to work until the first signs of crisis in the seventeenth century, when local finance, by now unable to meet its obligations with the royal authorities and, above all, its creditors, was subjected to a necessary reform of the municipal balance sheets. The method chosen was the fiscalización of the whole sector of municipal finance. The information required to accomplish the reform came from three enquiries carried out extensively in the whole kingdom over twenty years (1612-1633) ${ }^{48}$. Such enquires were first entrusted to judge-commissioners sent out to the provinces as representatives of the Viceroy and then to the officers of the main courts of the capital (Camera della Sommaria and Consiglio del Collaterale). They collected a huge amount of data which formed the information necessary to take action and remodel the local finances. Information thus established itself as an important tool in territorial government in the field of taxation as would happen few years later in Spain (1632-158) ${ }^{49}$. The results made possible to draw up documents called "stati discussi", setting out estimates based on the analysis of the financial situations of previous years, to be used to monitor local finance and correct its mistakes.

Through these documents, the local communities, the primary and greatest taxpayers in the Kingdom, should have had some certainty regarding their behaviour regarding tax matters in the future. In the specific field of tax evasion, action was taken against the barons not only to control unlawful claims on community resources, but also and above all to force them to fulfil their own tax obligations which were often not met locally. Attempts were also made to uncover fraud against local communities in the field of credit, which had expanded greatly in the previous decades and had become a destabilizing factor in the balance of local finance and its ability to fulfil its commitments towards the Treasury.

The complex operation adopted did not reach the pre-established aims of rebalancing, solvency, and fiscal compliance, due to the historical context (the Thirty Years War, economic and demographic crisis). However, it allowed a transition from uncertainty to risk, i.e. to move from a lack of knowledge

48. A. Bulgarelli LuKacs (2012a and 2012b).

49. B. Cárceles de Gea (2000). 
of the local financial situation to a state where all the variables in the budget were known and could be quantified ${ }^{50}$. A new fiscal pact was made with the municipalities of the Kingdom which constituted for the Naples government a reference point of knowledge and comparison, indispensable for any intervention in the local communities. Drawn up in the decades of the early seventeenth century, it was constantly referred to for about two centuries until the establishment of the feudal Commission in the Napoleonic Age.

50. Greater details in A. Bulgarelli LuKacs (2016), 277-283. 


\section{REFERENCES}

Alfani, G. BARBot, M. (2009), Ricchezza, valore, proprietà in età preindustriale, 1400-1850, Marsilio, Venezia.

Barbot, M. (2009), Stima, stime ed estimi. Prime indagini sulla valutazione di beni e persone nella Lombardia di antico regime, in G. Alfani, M. BARBot, (eds.) (2009), pp. 31-41.

Bermúdez, A. (1974): El corregidor en Castilla durante la Baja Edad Media (1348-1474), Departamento de Historia del Derecho, Murcia.

Bernardo Ares, J.M. (1993): Corrupción politica y centralización administrativa. La Hacienda de Proprios en la Córdoba de Carlos II, Universidad de Córdoba, Córdoba.

Bulgarelli Lukacs, A. (1993), L'imposta diretta nel Regno di Napoli in età moderna, Franco Angeli, Milano.

- (2004), Alla ricerca del contribuente. Fisco, catasto, gruppi di potere, ceti emergenti nel Regno di Napoli del XVIII secolo, Edizioni Scientifiche Italiane, Napoli.

- (2009), "La popolazione del Regno di Napoli nel primo Seicento (15951648). Analisi differenziale degli effetti ridistributivi della crisi e ipotesi di quantificazione delle perdite demografiche", Popolazione e storia, 2009/1, pp. 77-113.

- (2012a), La finanza locale sotto tutela. Regia Corte e comunità nel Regno di Napoli (secolo XVII), Marsilio, Venezia.

- (2012b), La finanza locale sotto tutela. I bilanci delle comunità nel Regno di Napoli (secoli XVII-XVIII), Marsilio, Venezia.

- (2016), "Far fronte alla crisi della finanza locale: nuovi strumenti contabili e nuovo patto fiscale tra governo e comunità locali nel Regno di Napoli (XVII secolo)", in Le crisi finanziarie. Gestione, implicazioni sociali e conseguenze nell'età preindustriale, Istituto Internazionale di storia economica "F. Datini", pp. 259-284.

Canet Aparisi, T. (1987): "Procedimientos de control de los oficiales regios en la corona de Aragón. Consideraciones sobre su tipología y evolución en la epoca foral moderna", Studis: Revista de Historia Moderna, 13, pp. 131-150.

CÁrceles de GeA, B. (1994), Fraude y Administración Fiscal en Castilla. La Comisión de Millones (1632-1658). Poder fiscal y privilegio jurídico-político, Banco de España- Servicio de Estudios. Estudios de Historia Económica, 28, Madrid. 
- (2000), Fraude y desobediencia fiscal en la corona de Castilla, 1621-1700, Consejería de Educación y Cultura, Valladolid.

Cervellino, L. (1686), Direzione ovvero guida delle Università di tutto il Regno di Napoli, Giuvan Francesco Paci, Napoli.

Chioccarello, B. (1721), Archivio della Reggia Giurisdizione del Regno di Napoli, Venezia.

Collantes de Terán de la Hera, M.J. (1998): "El judicio de residencia en Castilla a través de la doctrina jurídica de la Etad Moderna", Historia. Istituciones. Documentos, 25, pp. 151-184.

Colombo, E. (2009), Un estimo tra comunità e Stato. Contado di Vigevano, 1602-1667, in G. Alfani, M. Barbot, (eds.) (2009), pp. 63-75.

Del Treppo, M. (1986), "Il Regno aragonese", in Storia del Mezzogiorno, IV/1, Edizione del Sole, Roma, pp. 88-201.

Dincecco, M. (2010) "Fragmented Authority from Ancient Régime to Modernity: a Quantitative Analysis", Journal of Institutional Economics, 6, pp. 305-328

EPSTEIN, S.R. (2000), Freedom and Growth. The rise of states and markets in Europe, 1300-1750, Routledge, London and New York.

Estepa DíEz, C. (2003), Las Behetrías castellanas, Junta de Castilla y León. Valladolid.

FARAGLIA, N.F. (1883), Il Comune nell'Italia meridionale (110-1806), F. Tessitore, Napoli.

Fortea PÉrez, J.I. (1987), “Aproximación al estudio de las actitudes sociales ante el fisco: el fraude fiscal en la Corona de Castilla en el siglo XVI", Studia Storica. Historia Medieval, 5, pp. 99-110.

- (2003), "Quis custodit custodes? Los corregidores de Castilla y sus residencias (1558-1658)", en Vivir el siglo de Oro: poder, cultura, e historia en la época moderna. Estudios en homenaje al profesor Ángel Rodríguez Sánchez, Ediciones Universidad, Salamanca, pp. 179-222.

- (2012), "Los corregidores de Castilla bajo los Austrias: elementos para el estudio prosopogáfico de un grupo de poder (1588-1633)", Studia Historica. Historia Moderna, 34, pp. 97-144.

FourNIER, P.F., GuÉBIN, P. (1959), Enquêtes administratives d'Alfonse de Poitiers. Arrêts de son parlement tenu à Toulouse et textes annexes. 12491271, Imprimerie Nationale, Paris.

Galasso, G. (1975), Economia e società nella Calabria del Cinquecento, Feltrinelli, Milano. 
Garriga, C. (1991), "Control y disciplina de los oficiales públicos en Castilla: la visita del Ordenamiento de Toledo (1480)", Anuario de Historia del Derecho Español, 61, pp. 215-389.

GiURA, V. (1987), "Economia e società in un casale albanese di Calabra Citra nel XVIII secolo: Santa Sofia d'Epiro", in Studi in onore di Angelo Falzea, Napoli, ESI, Napoli, pp. 197-215.

Giustiniani, L., 1803-1808, Nuova collezione delle prammatiche del Regno di Napoli, stamperia Simoniana, Napoli.

GonZÁlez Alonso B. (1970): El corregidor castellano (1348-1808), Escuela Nacional de Administración Pública, Madrid.

- (1978), "El judicio de residencia en Castilla. I: Origen y evolución hasta 1480", Anuario de Historia del Derecho Español, 48, pp. 193-248.

Lalinde Abadia, J. (1965), "La purga de taula", en Homenaje a Jaime Vices Vives, vol. I, Universidad de Barcelona, Barcelona, pp. 499-523.

LEvI, G. (2003), “Aequitas vs fairness. Reciprocità ed equità fra età moderna ed età contemporanea”, Rivista di Storia Economica, 2, pp. 195-204.

Marotta, N.A. (1642), De collecta seu bonatenentia in hoc regno neapolitano, Typographia Secundini Roncalioli, Napoli.

Menjot, D., Martínez Sánchez, M. (2006), Fiscalidad de Estado y fiscalidad municipal en los reinos hispanicos medievales, Casa de Velázquez, Madrid.

Merchán Fernández, A.C. (1988), Gobierno Municipal y Administración Local en la España del Antiguo Regimen, Editorial Tecnos, Madrid.

Meuvret, J. (1971), "Comment les français du XVIIe siècle voyaient l'impot", in ID., Études d'histoire économique, Armand Colin, Paris, pp. 295308.

MonTI, A. (2003), Iudicare tamquam deus: i modi della giustizia senatoria nel ducato di Milano tra Cinque e Settecento, Giuffrè, Milano.

Morelli, S. (2012), Per conservare la pace. I Giustizieri del regno di Sicilia da Carlo I a Carlo II d'Angiò, Liguori, Napoli

Musi, A. (1989), “Fisco, religione e Stato nel Mezzogiorno d'Italia (secoli XVI-XVII)", in Fisco, religione Stato nell'età confessionale, Annali dell'Istituto storico italo-germanico, quaderno 26, il Mulino, Milano, pp. 427-458.

— (ed.) (2000), Le città nel Mezzogiorno nell'età moderna, ESI, Napoli. 
Peytavin, M. (2007), "Government/Administration. The Italian Kingdoms within the Spanish Monarchy", in T.J. DANDELET and J.A. MARINo (eds.), Spain in Italy. Politics, Society and Religion 1500-1700, Brill, Leiden, pp. 355-382.

Piccolo di Monforte, P. (1572), De forma appretii faciendi iuxta cap. reg. declarata, Napoli.

Russo, S. (1991), "La città e i suoi casali", in F. TATEO, Storia di Bari nell'antico regime, t. I, Laterza, Roma - Bari, pp. 79-85

Salvemini, B. (2000), "Sui presupposti materiali dell'identità locale in antico regime: le città della Puglia centrale fra XVI e XVIII secolo", in A. MusI, pp. 13-24.

- (2006), Il territorio sghembo. Forme e dinamiche degli spazi umani in età moderna, Edipuglia, Bari.

Sposato, P. (1965-1966), "Dati statistici sulla popolazione civile ed ecclesiastica nel viceregno di Napoli tra la prima e la seconda metà del Seicento", in Annali della scuola speciale per archivisti e bibliotecari dell'Università di Roma, a. V, 2, pp. 115-176 and a. VI, 1-2, pp. 33-86.

Sturdy, D.J. (1976), "Tax evasion, the Faux Nobles, and State Fiscalism: The example of the Géneralité of Caen, 1634-35”, French Historical Studies, 9, n. 4, pp. 549-572.

Vitale, G. (2010), “«Universitates» e «Officiales Regii» in età aragonese nel Regno di Napoli: un rapporto difficile”, Studi Storici, 51, pp. 53-72. 